\title{
Iz Plavtovega Kljukca (Pseudolus)
}

\section{Prevedla Nada Grošelj}

Zgodba je naslednja: Atenski mladenič Kalidor je zaljubljen v kurtizano Fojnikijo, ki pripada zvodniku Balionu, glavnemu negativcu v igri. V uvodnem prizoru Kalidor pokaže družinskemu sužnju Kljukcu (Pseudolus) pismo, v katerem ga Fojnikija prosi za pomoč, ker jo je kupil neki makedonski vojak za dvajset min; petnajst min je plačal vnaprej, preostalih pet pa naj bi prav tega dne prinesel njegov sel, ki bo dokazal svojo istovetnost $\mathrm{z}$ dogovorjenim znamenjem - pismom s pečatnim odtisom vojakovega portreta. Kljukec obljubi Kalidoru, da bo preprečil prodajo njegove ljubice. Ko prispe vojakov sel Grabež (Harpax), Kljukec od njega z zvijačo pridobi vojakovo pismo in prepoznavno znamenje, nato pa pošlje $\mathrm{k}$ Balionu drugega pretkanega sužnja, Pavijana (Simia), da se izdaja za vojakovega slugo in odpelje Fojnikijo na varno. Ta osrednji dogodek v drami - prevara Baliona - je prikazan v gornjem odlomku. - Prevod celotne komedije bo še v letu 2010 izšel pri Celjski Mohorjevi družbi.

\section{ČETRTO DEJANJE, DRUGI PRIZOR (956-1016)}

(Ulica v Atenah. Kljukec in Pavijan, preoblečen v vojaškega slugo, od strani opazujeta hišo zvodnika Baliona. Vrata so se odprla in ven prihaja Balion ritensko, ker se vmes ozira nazaj v hišo, kjer je na delu najet kuhar, pripadnik notorično tatinskega poklica.)

\section{Balion}

Tale kuhar je bolj fejst, kot sem ga presodil prej:

podržavil je samo vrček in skodelico.

Kljukec

(Pavijanu)

Slišiš, zdaj je pravi čas!

Pavijan

Isto mislim tudi jaz.

Kljukec

Le zvijačno kreni tja; jaz bom tu oprezoval. 


\section{Pavijan}

(krene v Balionovo smer in govori glasno, da bi ga ta slišal)

Ulice sem štel in ta šesta je od mestnih vrat;

v šesto ulico naj bi, kakor je dejal, zavil;

cifra hiše, bogme da, pa mi je povsem ušla.

Balion

Kdo, od kod je ta možak v plašču? Koga le bi rad?

Na pogled mi je neznan; kot da ni od tod doma.

Pavijan

Glej no, tamle je nekdo, ki mi bo razgnal meglo.

Balion

Točno proti meni gre. Le od kod se je tip vzel?

Pavijan

Ej, ti tamle, kozji fiks! Odgovori, kar želim!

Balion

Najprej se pozdravi, ne?

Pavijan

Zdravja ne delim kar vsem.

Balion

$\mathrm{Z}$ istim ti bom vrnil jaz.

Kljukec

Dobro je začel, ni kaj.

Pavijan

Reci, a poznaš ljudi, ki žive v tej ulici?

Balion

Sebe.

Pavijan

Silno redki so, ki lahko to trdijo;

od desetih le en sam človek sebe res pozna.

Kljukec

Rešen sem; že klobasá.

Pavijan

Tukaj iščem lopova,

prevaranta, gangsterja in zločinca.

Balion

To sem jaz:

moje vzdevke je naštel. Da bi zinil še ime!

- Kdo je to?

Pavijan

Zvodnik mendà: Balion.

Balion

Kot sem dejal. 
- Jaz sem tisti, mladi možz, ki ga iščeš.

Pavijan

$$
\text { Balion? }
$$

Balion

On osebno.

979, 980

Pavijan

Zgledaš bolj kot specialist za vlom.

Balion

Dvakrat bi premislil, ne, preden bi mi segel $\mathrm{v} z ̌ e p ?$

Pavijan

Moj gospod mi je dejal, naj ti izročim pozdrav.

Razen tega imam ukaz, naj ti tole pismo dam.

Balion

Kdo je to ukazal?

Kljukec

Joj, človek je zabredel v zos;

saj imena ne pozna!

Balion

Kdo je, praviš, to poslal?

Pavijan

Kar podobo si poglej in mi ti ime povej,

da se bom prepričal sam, če si Balion.

Balion

$$
\text { No, daj. }
$$

Pavijan

Vzemi. Prepoznaš pečat?

Balion

$$
\text { Kajpak, to je Udriga* }
$$

s kožo in kostmi; poznam. - Ej, ime je »Udriga«!

Pavijan

Vidim, da sem storil prav, ko sem tebi pismo dal, saj, kot slišim, dobro veš Udrigajevo ime.

Balion

Kaj počne?

Pavijan

Pač to, kar vsak dober borec in junak.

Ampak meni se mudi; daj, preberi en dva tri pismo in prevzemi cvenk, žensko pa brž pošlji ven.

Če ne pridem še nocoj v Sikion, bo zame joj; moj gospod je tak tiran.

Udriga: Vojakovo izvirno (grško) ime je Polymachaeroplagides, »sin mnogih udarcev z mečem «. 
Balion

Dobro vem, saj ga poznam.

Pavijan

Torej hitro beri!

Balion

Saj; le ne moti me ves čas!

»To pismo je od Udriga, vojaka,

namenjeno zvodniku Balionu,

opremljeno s pečatom, kot določa

1000

vzajemni sporazum.«

Pavijan

Balion

Pečat je spredaj.

To vidim in pečat poznam. Povej no,

kaj pisma níkdar ne začne s pozdravom?

Pavijan

Hja, Balion, vojaška etiketa:

vojak deli z desnico mir in zdravje

prijateljem, sovražnikom pa rane.

Ti pa, kot si začel, skrbno razišči,

kaj piše v pismu!

Balion

Kar našpiči uhlje.

»Moj sluga Grabež, ki se je oglasil -«

si ti ta Grabež?

Pavijan

Sem, in to še kakšen!

Balion

»Oglasil s temle pismom, naj ti plača.

Dekle mi pošlji sèm v njegovem spremstvu.

Pozdrav zaslužijo samo zaslužni;

če bi zaslužil, bi te zdaj pozdravil.«

Pavijan

Pa zdaj?

Balion

Ti daš srebro in vzameš punco.

Pavijan

Kdo zavlačuje?

Balion

Stopi noter. -

Pavijan

Dobro. - 
ČETRTO DEJANJE, TRETJI PRIZOR (1017-1037)

Kljukec

Svoj živ dan nisem videl barabina, bolj zvitega od tega Pavijana.

Pred njim me grabi groza in tesnoba, da ne bi prelisičil tudi mene -

da ne bi mene samega nabodel, če bo ugodna prilika, baraba!

Zapletov nočem, ker mi je pri srcu.

Zdaj trojni strah trpim iz treh razlogov:

bojim se, prvič, svojega pajdaša, da ne bi presedlal v nasprotni tabor.

Bojim se tudi, da se zdajle vrne gospod in bosta lovca odlovljena, pa še, da se bo vrnil pravi Grabež, še preden moj odnese pete s punco. Uničen sem! Sto let ju ni iz hiše. Srce mi čaka v grlu z vso prtljago, da mi, če se prikaže tip brez punce, na vrat na nos izskoči in pobegne. (Iz Balionove hiše pride Pavijan s Fojnikijo.)

- Na konju sem: preslepil sem stražarje! 